\title{
A prospective interventional study to examine the effect of a silver alloy and hydrogel-coated catheter on the incidence of catheter-associated urinary tract infection
}

\author{
Patrick HY Chung, Carol WY Wong, Christopher KC Lai *, HK Siu, Dominic NC Tsang, KY Yeung, \\ Dennis KM Ip, Paul KH Tam
}

\begin{abstract}
A B S T R A C T
Introduction: Catheter-associated urinary tract infection is a major hospital-acquired infection. This study aimed to analyse the effect of a silver alloy and hydrogel-coated catheter on the occurrence of catheter-associated urinary tract infection.
\end{abstract}

Methods: This was a 1-year prospective study conducted at a single centre in Hong Kong. Adult patients with an indwelling urinary catheter for longer than 24 hours were recruited. The incidence of catheter-associated urinary tract infection in patients with a conventional latex Foley catheter without hydrogel was compared with that in patients with a silver alloy and hydrogel-coated catheter. The most recent definition of urinary tract infection was based on the latest surveillance definition of the National Healthcare Safety Network managed by Centers for Disease Control and Prevention.

Results: A total of 306 patients were recruited with a similar ratio between males and females. The mean (standard deviation) age was 81.1 (10.5) years. The total numbers of catheter-days were 4352 and 7474 in the silver-coated and conventional groups, respectively. The incidences of catheter-associated urinary tract infection per 1000 catheter-days were 6.4 and 9.4 , respectively $(\mathrm{P}=0.095)$. There was a $31 \%$ reduction in the incidence of catheter-associated urinary tract infection per 1000 catheter-days in the silver-coated group. Escherichia coli was the most commonly involved pathogen $(36.7 \%)$ of all cases.

This article was published on $17 \mathrm{Feb}$ 2017 at www.hkmj.org. Subgroup analysis revealed that the protective effect of silver-coated catheter was more pronounced

a respective $48 \%(\mathrm{P}=0.027)$ and $42 \% \quad(\mathrm{P}=0.108)$ reduction in incidence of catheter-associated urinary tract infection. The mean catheterisation time per person was the longest in patients using a silver-coated catheter (17.0 days) compared with those using a conventional (10.8 days) or both types of catheter ( 13.6 days) [ $\mathrm{P}=0.01]$.

Conclusions: Silver alloy and hydrogel-coated catheters appear to be effective in preventing catheter-associated urinary tract infection based on the latest surveillance definition. The effect is perhaps more prominent in long-term users and female patients.

Hong Kong Med J 2017;23:239-45

DOI: $10.12809 / \mathrm{hkmj} 164906$
${ }^{1}$ PHY Chung, FRCSEd(Paed), FHKAM (Surgery)
${ }^{1}$ CWY Wong, MB, BS, MRCSEd
${ }^{2}$ CKC Lai *, MB, ChB, FRCPath
${ }^{3} \mathrm{HK}$ Siu, BSc (Statistics), MPhil (CUHK)
2,3 DNC Tsang, MB, BS, FRCPath
${ }^{4} \mathrm{KY}$ Yeung, MNurs, BNurs
${ }^{5}$ DKM Ip, MB, BS, MPhil(Epidemiology)(Cantab)
${ }^{1}$ PKH Tam, FRCS (Edin, Glasg, Irel), FHKAM (Surgery)
Department of Surgery, Li Ka Shing Faculty of Medicine, The University of Hong Kong, Pokfulam, Hong Kong
${ }^{2}$ Department of Pathology, Queen Elizabeth Hospital, Jordan, Hong Kong Chief Infection Control Officer's Office, Hospital Authority, Hong Kong
Infection Control Team, Central Nursing Department, Kowloon Hospital, Argyle Street, Hong Kong
${ }^{5}$ School of Public Health, Li Ka Shing Faculty of Medicine, The University of Hong Kong, Pokfulam, Hong Kong

* Corresponding author: laikcc@ha.org.hk

New knowledge added by this study

- The use of a silver alloy and hydrogel-coated (SAH) catheter has the potential to reduce catheter-associated urinary tract infection (CA-UTI), especially in certain subgroups of patients (long-term users and female patients).

Implications for clinical practice or policy

- The use of a SAH catheter potentially reduces the incidence of CA-UTI. This will lead to less morbidity and medical costs associated with CA-UTI.

- This study provides pilot data for future research.

\section{Introduction}

Catheter-associated urinary tract infection (CA- 


\section{一項前瞻性介入研究以探討銀合金水凝膠塗層導 管對出現導管相關性尿道威染的影響 \\ 鍾浩宇、黃詠欣、賴貫之、邵漢基、曾艾壯、楊健玉、 葉啟明、譚廣亨}

引言：導管相關性尿道感染是醫院內感染中最常見的一種。本研究旨 在分析銀合金水凝膠塗層導管對出現導管相關性尿道感染的影響。

方法: 這前瞻性研究在香港一個單一中心內進行, 為期一年。研究對 象為使用留置導尿管超過 24 小時的成年病人。並將使用銀合金水凝膠 塗層導管的病人和使用傳統沒有水凝膠的Foley（乳膠）導管的病人進 行比較, 找出兩組導管相關性尿道感染的發生率。病人是否有尿道感 染是按美國疾病管制中心成立的國家健康照護安全網絡的最新定義來 判斷

結果：共306名病人參與本研究, 他們平均年齡 (標準差) 為8 81.1 （10.5）歲, 男女比例相若。銀合金水凝膠塗層導管和傳統Foley導管 兩組的導管使用人日分別為 4352 天和 7474 天, 而每一千導管人日的導 管相關性尿道感染發生率分別為6.4和9.4（P=0.095）。銀合金水凝膠 塗層導管組別的每一千導管人日的導管相關性尿道感染下降了 $31 \%$ 。 大腸桿菌是所有病人中最常見的病原體 $(36.7 \%)$ 。亞組分析顯示銀 合金水凝膠塗層導管的保護作用在長期使用者以及女性病人當中更加 明顯, 前者的導管相關性尿道感染發生率減少了 $48 \% （ \mathrm{P}=0.027 ）$, 後 者減少了 $42 \% （ \mathrm{P}=0.108 ）$ 。留置導管的時間方面, 使用銀合金水凝膠 塗層導管的病人為最長 (平均17.0天), 使用傳統Foley導管的病人為 10.8 天, 曾使用兩種導管的則為13.6天 $(\mathrm{P}=0.01)$

結論：根據對尿道感染的最新監測定義, 銀合金水凝翏塗層導管似乎 能有效預防導管相關性尿道感染。此效應在長期使用者和女性病人當 中可能更明顯。 bacteriuria (ASB) alone or in combination with symptomatic UTI as the endpoint so their clinical relevance was called into question. We conducted a prospective, interventional study to provide additional data on the effectiveness of the noble metal alloy urinary catheter in the prevention of CA-UTI, using the updated surveillance definition of National Healthcare Safety Network (NHSN) managed by the Centers for Disease Control and Prevention (CDC). This surveillance definition was adopted in 2009 and modified the criteria for symptomatic infection, as well as adding a category and definition for asymptomatic bacteraemic UTI together with the removal of ASB completely. ${ }^{5}$ To study the effect on ASB, we adopted the criteria used in the Infectious Diseases Society of America practice guideline developed in 2009.6

\section{Methods}

This single-centre 1-year prospective study was completed in 2012 in a regional rehabilitation hospital in Hong Kong. The study population was in-patients in two medical rehabilitation wards. All patients over 18 years of age on either of the wards during the study period with an indwelling catheter for longer than 24 hours were recruited after giving informed consent. Patients who underwent suprapubic catheterisation, single in-and-out catheterisation for collection of a urine specimen, intermittent catheterisation for urine drainage, catheterisation for less than 24 hours, or who were catheterised with a silicone Foley catheter, and those who had been treated with antibiotics for a UTI were excluded from the study. Both of the study wards rotated through the two different interventions in two 6-month periods in order to act as a self-control to minimise the potential problem of variability in medical and nursing practice that might affect the outcomes. Conventional latex Foley catheters without hydrogel (sized Fr 12, 14, and 16) were used for catheterisation on both wards during the first half of the study period; SAH catheters (sized Fr 12,14 , and 16) were used during the second half of the study period. If a catheter was changed due to the presence of infection, the appropriate catheter according to the month of the study was used. Thus it was possible for patients who required a catheter for a long time and underwent catheter exchange to be exposed to both types of urinary catheter (Fig 1).

The definition of CA-UTI was adopted and modified from the CDC/NHSN definition of symptomatic UTI (Appendix ${ }^{5,6}$ ). Routine, regular screening and clinical urine samples were collected from all subjects according to the hospital protocol. Routine urine samples were taken from all subjects at four fixed time-points: on admission, on catheterisation, before removal of the catheter, and before hospital discharge. Screening samples were 
taken weekly. Clinical samples were taken whenever a patient demonstrated symptoms and signs of UTI, or as part of a sepsis workup. The incidence of CA-UTI in the two groups was analysed in terms of the absolute number of CA-UTI episodes and the number of CA-UTI episodes per 1000 catheterdays. Values were expressed as mean \pm standard deviation. Comparison between the two groups was performed by Pearson's Chi squared test, Student's $t$ test, and one-way analysis of variance test when appropriate with a two-sided significance level of 0.05 . The rate ratio of CA-ASB and CA-UTI between the two groups was compared by exact Poisson test for rate ratio. The occurrence of CA-UTI between the two groups was also analysed with Kaplan-Meier analysis. Results were analysed using the Statistical Package for the Social Sciences (Windows version 21.0; SPSS Inc, Armonk [NY], US) and R version 3.1.2.

This study was done in accordance with the principles outlined in the Declaration of Helsinki.

\section{Results}

During the 1-year study period, 306 patients were recruited. The male-to-female ratio was $1: 1.13$ and the mean age was $81.1 \pm 10.5$ years (Table 1 ). Overall, 187 patients used a conventional catheter only, 36 patients used a SAH catheter only, and 83 patients used both a conventional and a SAH catheter (Fig 1).

The total numbers of catheter-days were 4352 and 7474 in the $\mathrm{SAH}$ and conventional groups, respectively. The numbers of CA-UTI episodes were 28 and 70, respectively. Thus the incidences of CA-UTI per 1000 catheter-days in the SAH and conventional groups were 6.4 and 9.4, respectively $(\mathrm{P}=0.095)$ with a rate ratio of 0.69 (95\% confidence interval $[\mathrm{CI}], 0.42-1.08)$. There was a $31 \%$ reduction in
CA-UTI incidence in the SAH group. Using KaplanMeier analysis and log-rank test, SAH catheter was associated with a significantly lower rate of CA-UTI $(\mathrm{P}=0.045$; Fig 2). Regarding $\mathrm{CA}-\mathrm{ASB}$, the incidences per 1000 catheter-days in the SAH and conventional groups were 70.8 and 67.2 , respectively $(\mathrm{P}=0.467)$ with a rate ratio of 1.05 (95\% CI, 0.91-1.22). Results are summarised in Table 2. Blood cultures were taken from patients who developed CA-UTI. In both groups, none of the patients with CA-UTI developed bacteraemia. Escherichia coli was the most commonly involved urinary pathogen and accounted for $36.7 \%$ of all cases, followed by Candida albicans (17.3\%) and Proteus mirabilis (14.3\%) [Table 3]. The same pathogens were observed in both groups.

This study was not a randomised controlled trial. Thus to eliminate patient selection bias, a subgroup analysis was performed among those patients who used both types of catheter $(n=83)$. These patients had more catheters used and more

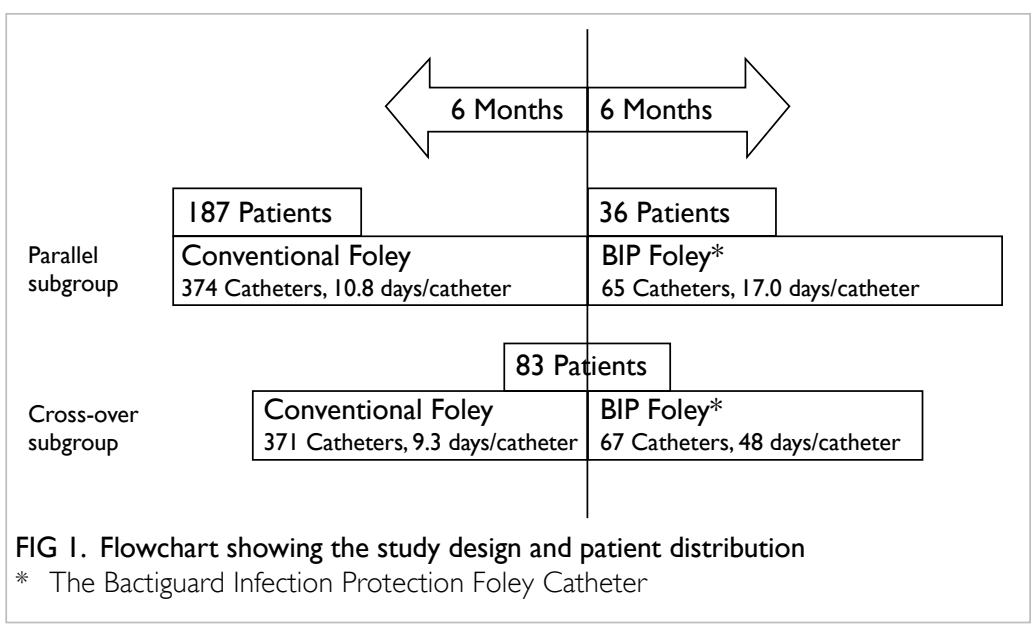

TABLE I. Characteristics of the study population, specimens collected, and catheter used

\begin{tabular}{|c|c|c|c|c|c|}
\hline \multirow[t]{2}{*}{ Characteristic } & \multicolumn{3}{|c|}{ Mean \pm standard deviation } & \multicolumn{2}{|c|}{ Independent $t$ test (female vs male) } \\
\hline & $\begin{array}{l}\text { All patients } \\
(n=306)\end{array}$ & $\begin{array}{c}\text { Female patients } \\
(n=162)\end{array}$ & $\begin{array}{l}\text { Male patients } \\
\quad(n=144)\end{array}$ & $P$ value & $\begin{array}{l}\text { Mean difference }(95 \% \\
\text { confidence interval) }\end{array}$ \\
\hline Age (years) & $81.1 \pm 10.5$ & $82.6 \pm 10.3$ & $79.5 \pm 10.5$ & 0.01 & 3.1 (0.7 to 5.4$)$ \\
\hline \multicolumn{6}{|l|}{ No. of specimens collected } \\
\hline Screening & $7.6 \pm 13.9$ & $7.6 \pm 13.0$ & $7.5 \pm 14.9$ & 0.95 & 0.1 (-3.0 to 3.2$)$ \\
\hline Clinical & $0.4 \pm 0.7$ & $0.4 \pm 0.7$ & $0.4 \pm 0.8$ & 0.98 & $0.0(-0.2$ to 0.2$)$ \\
\hline \multicolumn{6}{|l|}{ No. of catheters used } \\
\hline Silver alloy and hydrogel-coated & $0.8 \pm 1.5$ & $0.8 \pm 1.5$ & $0.7 \pm 1.5$ & 0.44 & $0.1(-0.2$ to 0.5$)$ \\
\hline Conventional & $2.2 \pm 2.6$ & $2.1 \pm 2.6$ & $2.2 \pm 2.8$ & 0.81 & $-0.1(-0.7$ to 0.5$)$ \\
\hline All catheters & $2.9 \pm 3.5$ & $3.0 \pm 3.4$ & $2.9 \pm 3.7$ & 0.88 & $0.1(-0.7$ to 0.9$)$ \\
\hline \multicolumn{6}{|l|}{ No. of catheter-days } \\
\hline Silver alloy and hydrogel-coated & $14.2 \pm 35.3$ & $14.7 \pm 34.2$ & $13.7 \pm 36.6$ & 0.79 & $1.1(-6.9$ to 9.0$)$ \\
\hline Conventional & $24.4 \pm 33.4$ & $24.4 \pm 33.0$ & $24.5 \pm 33.9$ & 0.97 & $-0.2(-7.7$ to 7.4$)$ \\
\hline All catheters & $38.6 \pm 59.8$ & $39.1 \pm 57.2$ & $38.2 \pm 62.9$ & 0.89 & $0.9(-12.6$ to 14.4$)$ \\
\hline
\end{tabular}


catheter-days than those patients who used only one type of catheter (Table 4a). This was due to study design where longer-term users had a higher chance of exposure to both types of urinary catheter. Among them, the total numbers of catheter-days were 3210 and 3457 in the SAH and conventional groups, respectively. The numbers of CA-UTI episodes were 17 and 35, respectively. This resulted in the incidences of CA-UTI per 1000 catheter-days in the SAH and conventional groups being 5.3 and 10.1, respectively $(\mathrm{P}=0.027)$ with a rate ratio of $0.52(95 \%$

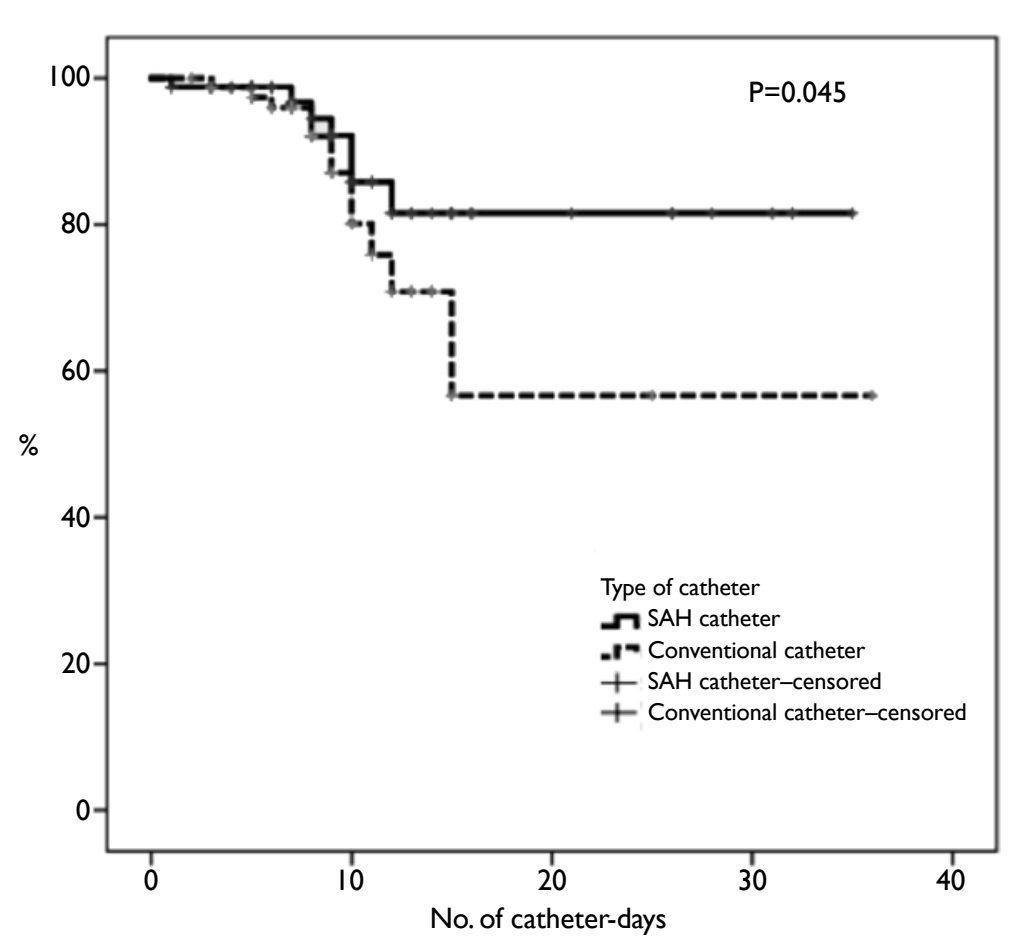

FIG 2. Comparison of CA-UTI occurrence between SAH and conventional catheters in the entire study population using Kaplan-Meier analysis Abbreviations: $\mathrm{CA}-\mathrm{UTI}=$ catheter-associated urinary tract infection; $\mathrm{SAH}=$ silver alloy and hydrogel-coated
CI, 0.27-0.96). There was a statistically significant reduction of $48 \%$ in CA-UTI incidence in the SAH group (Table $4 \mathrm{~b}$ ). Because the catheters were exchanged when an infection occurred, the CA-UTI reducing effect resulted in less need to exchange a SAH catheter-the mean catheterisation time per person was 17.0 days for a SAH catheter compared with 10.8 days for a conventional catheter and 13.6 days for patients using both catheters (Table 4a).

To examine the presence of outcome difference in relation to gender in the entire study population, we also performed a subgroup analysis based on gender differences (Table 4c). In male patients $(n=144)$, the number of CA-UTI episodes was 15 in the SAH group (total catheter-days, 1966) and 33 in the conventional group (total catheter-days, 3529). The incidences of CA-UTI per 1000 catheter-days in the SAH and conventional groups were 7.6 and 9.4, respectively $(\mathrm{P}=0.551)$ with a rate ratio of 0.82 (95\% CI, 0.41-1.54). For female patients $(n=162)$, the number of CA-UTI episodes was 13 in the SAH group (total catheter-days, 2386) and 37 in the conventional group (total catheter-days, 3945). The incidences of CA-UTI per 1000 catheter-days in the $\mathrm{SAH}$ and conventional groups were 5.4 and 9.4, respectively $(\mathrm{P}=0.108)$, with a rate ratio of $0.58(95 \%$ CI, 0.28-1.12).

\section{Discussion}

Urinary tract infection is one of the most commonly encountered infections in daily clinical practice and the majority of cases are catheter-related. Although a number of clinical practices such as aseptic technique for catheter insertion, closed drainage systems, and shorter duration of catheterisation have been introduced in an attempt to reduce the onset of CA-UTI, the incidence remains high.,7 Therefore, research for strategies or new technologies to prevent CA-UTI is still needed. Since the early 1990s, research has focused on different antiinfective catheter-coating materials but results have

TABLE 2. Overall comparison of CA-UTI and CA-ASB episodes between SAH catheters and conventional catheters

\begin{tabular}{lcccc}
\hline Variable & $\begin{array}{c}\text { SAH group } \\
\text { (a) }\end{array}$ & $\begin{array}{c}\text { Conventional group } \\
\text { (b) }\end{array}$ & $\begin{array}{c}\text { Rate ratio a/b (95\% } \\
\text { confidence interval) }\end{array}$ & $\begin{array}{c}\text { P value (exact Poisson } \\
\text { test for rate ratio) }\end{array}$ \\
\hline No. of patients & 119 & 270 & - & - \\
No. of catheters & 159 & 635 & - & - \\
No. of catheter-days & 4352 & 7474 & - & - \\
CA-ASB episodes & 308 & 502 & - & - \\
CA-ASB episodes/1000 catheter-days & 70.8 & 67.2 & $1.05(0.91-1.22)$ & 0.467 \\
CA-UTI episodes & 28 & 70 & - & - \\
CA-UTI episodes/1000 catheter-days & 6.4 & 9.4 & $0.69(0.42-1.08)$ & 0.095 \\
\hline
\end{tabular}

Abbreviations: CA-ASB = catheter-associated asymptomatic bacteriuria; CA-UTI = catheter-associated urinary tract infection; SAH = silver alloy and hydrogel-coated 
TABLE 3. Organisms identified from CA-UTI specimens (some specimens showed mixed flora)

\begin{tabular}{|c|c|c|c|}
\hline Organisms & SAH group & Conventional group & Total \\
\hline Gram-negative organisms & 26 & 92 & \\
\hline (All ESBL producers) & 8 & 23 & \\
\hline \multicolumn{4}{|l|}{ Enterobacteriaceae } \\
\hline Escherichia coli & 12 & 24 & 36 \\
\hline (ESBL producers) & (8) & (15) & \\
\hline Proteus mirabilis & 5 & 9 & 14 \\
\hline (ESBL producers) & (0) & (4) & \\
\hline Klebsiella pneumoniae / species & 4 & 6 & 10 \\
\hline (ESBL producers) & (0) & (1) & \\
\hline Other Enterobacteriaceae & 2 & 8 & 10 \\
\hline (ESBL producers) & (0) & (3) & \\
\hline Pseudomonas aeruginosa / species & 1 & 12 & 13 \\
\hline Acinetobacter species & 2 & 1 & 3 \\
\hline Gram-positive organisms & 7 & 11 & \\
\hline Enterococcus species & 5 & 7 & 12 \\
\hline Methicillin-resistant Staphylococcus aureus & 2 & 3 & 5 \\
\hline Coagulase-negative Staphylococcus & 0 & 1 & 1 \\
\hline Fungi & 5 & 22 & \\
\hline Candida albicans & 3 & 14 & 17 \\
\hline Candida species & 2 & 8 & 10 \\
\hline Total No. of positive samples & 28 & 70 & 98 \\
\hline
\end{tabular}

Abbreviations: $\mathrm{CA}-\mathrm{UTI}$ = catheter-associated urinary tract infection; $\mathrm{ESBL}=$ extended spectrum beta lactamase; $\mathrm{SAH}=$ silver alloy and hydrogel-coated

been generally inconclusive. Bactiguard-coated Foley catheters, an essential noble metal (gold, silver, and palladium) alloy and hydrogel-coated catheter, have been introduced to slow bacterial colonisation.

In the early 2000s, a randomised cross-over study by Karchmer et $\mathrm{al}^{8}$ demonstrated that the risk of UTI could be decreased by $21 \%$ on wards and by $32 \%$ among patients when a noble metal alloy catheter was used instead of a conventional catheter. Since then, more studies to compare anti-infective urinary catheters with conventional urinary catheters have been carried out. The noble metal alloy indwelling catheter has been shown in multiple large clinical trials and smaller case studies to reduce the incidence of CA-UTI, when compared with conventional catheters. $^{9-15}$ These studies have examined endpoints such as bacteriuria and symptomatic CA-UTI, or surveillance-defined UTI. ${ }^{8,16,17}$ In a study by Pickard et al, $^{17}$ noble metal alloy catheters were found to be ineffective in reducing the incidence of symptomatic surveillance-defined UTI when used in short-term (mean, 2 days) surgical patients and they did not support the routine use of these catheters in this patient group. Lack of effect is not surprising due to the short catheterisation time and low-risk patient group. In a more recent multicentre cohort study in
2014, Lederer et $\mathrm{al}^{4}$ examined the impact of noble metal alloy catheters on symptomatic CA-UTI and antibiotic use based on the NHSN surveillance and concluded that a $58 \%$ relative reduction $(\mathrm{P}<0.0001)$ in NHSN-defined CA-UTI rate was observed and $60 \%$ fewer antibiotics were used when compared with conventional catheters.

In the present study, we were able to demonstrate a $31 \%$ reduction in the incidence of CA-UTI episodes per 1000 catheter-days in the SAH group although it did not reach statistical significance, likely due to too small study groups. We believe that the incidence rate per catheterdays is a more appropriate comparison to reflect the risk of infection associated with different types of catheter as it also takes into account the duration of catheterisation, which is known to be an important factor associated with the incidence of CA-UTI. This is also reflected by the fact that the noble metal alloy catheter can be left in situ for the longest period of time. Although the cost of each SAH catheter (approximately $\mathrm{HK} \$ 100$ ) is higher than that of a conventional catheter (approximately $\mathrm{HK} \$ 15$ ), we believe the benefit of longer duration and potential reduction in CA-UTI justify its use.

With subgroup analysis, the effect of a noble 
TABLE 4. (a) Characteristics of patients who used both types of catheter, SAH catheter only, or conventional catheter only. (b) Comparison of CA-UTI and CA-ASB incidences between SAH and conventional catheters in 83 patients who used both types of catheter (cross-over group). (c) Comparison of CA-UTI and CA-ASB incidences between SAH and conventional catheters in male and female patients

(a)

\begin{tabular}{|c|c|c|c|c|}
\hline & \multicolumn{3}{|c|}{ No. of patients or mean \pm SD } & \multirow[t]{2}{*}{$P$ value } \\
\hline & $\begin{array}{l}\text { Both types of catheter } \\
\qquad(n=83)\end{array}$ & $\begin{array}{l}\text { SAH catheter only } \\
(n=36)\end{array}$ & $\begin{array}{c}\text { Conventional catheter } \\
\text { only }(n=187)\end{array}$ & \\
\hline Sex & & & & $0.41^{*}$ \\
\hline Female & 49 & 19 & 94 & \\
\hline Male & 34 & 17 & 93 & \\
\hline Diabetes mellitus & & & & $0.97^{\star}$ \\
\hline Yes & 17 & 8 & 38 & \\
\hline No & 66 & 28 & 149 & \\
\hline Age (years) & $79.2 \pm 12.5$ & $82.8 \pm 10.2$ & $81.7 \pm 9.5$ & $0.12 \dagger$ \\
\hline No. of catheters per patient (all catheters) & $5.5 \pm 5.6$ & $1.9 \pm 1.6$ & $2.0 \pm 1.4$ & $<0.001 \dagger$ \\
\hline No. of catheter-days per patient (all catheters) & $80.3 \pm 97.2$ & $31.7 \pm 38.7$ & $21.5 \pm 18.4$ & $<0.001 \dagger$ \\
\hline Average days per catheter per person & $13.6 \pm 4.8$ & $17.0 \pm 9.8$ & $10.8 \pm 4.9$ & $0.01 \dagger$ \\
\hline
\end{tabular}

* Chi squared test

† One-way analysis of variance

(b)

\begin{tabular}{lcccc}
\hline & $\begin{array}{c}\text { SAH catheter } \\
\text { (a) }\end{array}$ & $\begin{array}{c}\text { Conventional } \\
\text { catheter (b) }\end{array}$ & $\begin{array}{c}\text { Rate ratio a/b (95\% } \\
\text { confidence interval) }\end{array}$ & $\begin{array}{c}\text { P value (exact Poisson } \\
\text { test for rate ratio) }\end{array}$ \\
\hline No. of catheters & 67 & 371 & & \\
No. of catheter-days & 3210 & 3457 & & \\
No. of days per catheter & 48 & 9.3 & & 0.322 \\
CA-ASB episodes & 206 & 201 & $1.10(0.90-1.34)$ & \\
CA-ASB episodes/1000 catheter-days & 64.2 & 58.1 & & 0.027 \\
\hline CA-UTI episodes & 17 & 35 & $0.52(0.27-0.96)$ & \\
\hline CA-UTI episodes/1000 catheter-days & 5.3 & 10.1 & & \\
\hline
\end{tabular}

(c)

\begin{tabular}{|c|c|c|c|c|}
\hline & $\begin{array}{l}\text { SAH catheter } \\
\text { (a) }\end{array}$ & $\begin{array}{c}\text { Conventional } \\
\text { catheter (b) }\end{array}$ & $\begin{array}{l}\text { Rate ratio } \mathrm{a} / \mathrm{b} \text { (95\% } \\
\text { confidence interval) }\end{array}$ & $\begin{array}{c}P \text { value (exact Poisson } \\
\text { test for rate ratio) }\end{array}$ \\
\hline \multicolumn{5}{|l|}{ Male patients $(n=144)$} \\
\hline No. of patients & 51 & 127 & & \\
\hline No. of catheters & 98 & 318 & & \\
\hline No. of catheter-days & 1966 & 3529 & & \\
\hline CA-ASB episodes & 134 & 211 & & \\
\hline CA-ASB episodes $/ 1000$ catheter-days & 68.2 & 59.8 & $1.14(0.91-1.42)$ & 0.239 \\
\hline CA-UTI episodes & 15 & 33 & & \\
\hline CA-UTI episodes/1000 catheter-days & 7.6 & 9.4 & $0.82(0.41-1.54)$ & 0.551 \\
\hline \multicolumn{5}{|l|}{ Female patients $(n=162)$} \\
\hline No. of patients & 68 & 143 & & \\
\hline No. of catheters & 132 & 346 & & \\
\hline No. of catheter-days & 2386 & 3945 & & \\
\hline CA-ASB episodes & 174 & 291 & & \\
\hline CA-ASB episodes/1000 catheter-days & 72.9 & 73.8 & $0.99(0.81-1.20)$ & 0.924 \\
\hline CA-UTI episodes & 13 & 37 & & \\
\hline CA-UTI episodes/1000 catheter-days & 5.4 & 9.4 & $0.58(0.28-1.12)$ & 0.108 \\
\hline
\end{tabular}

Abbreviations: $\mathrm{CA}-\mathrm{ASB}$ = catheter-associated asymptomatic bacteriuria; $\mathrm{CA}-\mathrm{UTI}=$ catheter-associated urinary tract infection; SAH = silver alloy and hydrogel-coated; $\mathrm{SD}=$ standard deviation 
metal alloy catheter on reduction of CA-UTI was more prominent in long-term users and female patients. In patients who used both catheters and who served as their own control, a significant reduction ( $48 \%, \mathrm{P}=0.027$ ) was observed in the $\mathrm{SAH}$ group. The same reduction was not observed in those who used only one type of urinary catheter whose number of catheters used and catheterdays were significantly fewer (Table $4 a$ and $4 b$ ). We cannot give an exact explanation for this observation but we believe the protective effect of Bactiguard catheters is best seen in patients who require longterm urinary catheterisation. Nonetheless, it must be emphasised that the effect due to mixed use of catheters is unknown. The reduction in CA-UTI was also slightly more prominent in female patients (rate ratio of CA-UTI episodes per 1000 catheterdays, 0.58; Table 4c). Whether these are genuine and significant findings will warrant future randomised controlled studies to confirm.

This study has several limitations. First, this was a non-randomised study with a lack of blinding of outcome observers. Second, some patients might have used both catheters and the effects of each catheter type might have confounded the results. Third, as patients were recruited from a regional rehabilitation hospital, their underlying different medical conditions and risk factors might have affected the outcomes. As patients admitted during the two 6-month periods were incomparable, confounding by underlying risk factors for CA-UTI could not be excluded.

\section{Conclusions}

Our findings suggest that SAH-coated catheters may be effective in reducing CA-UTI based on CDC's NHSN surveillance definition. The effect seems to be more pronounced in high-risk patients such as longterm users and female patients. Future randomised controlled studies on this subject should be carried out based on these pilot data.

\section{Appendix}

Additional material related to this article can be found on the HKMJ website. Please go to <http:// www.hkmj.org $>$, and search for the article.

\section{Declaration}

All authors have disclosed no conflicts of interest.

\section{References}

1. Kong MY. Systematic review of the effective approach for limiting urinary catheter use and duration to reduce nosocomial catheter-associated urinary tract infections in hospitalized patients. Hong Kong: Faculty of Health and Social Sciences, the Hong Kong Polytechnic University; 2010.
2. Centers for Disease Control. Public health focus: surveillance, prevention, and control of nosocomial infections. MMWR Morb Mortal Wkly Rep 1992;41:783-7.

3. Maki DG, Tambyah PA. Engineering out the risk for infection with urinary catheters. Emerg Infect Dis 2001;7:342-7.

4. Lederer JW, Jarvis WR, Thomas L, Ritter J. Multicenter cohort study to assess the impact of a silver-alloy and hydrogel-coated urinary catheter on symptomatic catheter-associated urinary tract infections. J Wound Ostomy Continence Nurs 2014;41:473-80.

5. Division of Healthcare Quality Promotion, Centers for Disease Control and Prevention. The National Healthcare Safety Network manual. Atlanta, GA: Centers for Disease Control and Prevention; 2009.

6. Hooton TM, Bradley SF, Cardenas DD, et al. Diagnosis, prevention, and treatment of catheter-associated urinary tract infection in adults: 2009 International Clinical Practice Guidelines from the Infectious Diseases Society of America. Clin Infect Dis 2010;50:625-63.

7. Salgado CD, Karchmer TB, Farr BM. Prevention of catheter-associated urinary tract infection. In: Wenzel RP, editor. Prevention and control of nosocomial infections. 4th ed. Philadelphia, PA: Lippincott Williams \& Wilkins; 2003: 297-311.

8. Karchmer TB, Giannetta ET, Muto CA, Strain BA, Farr $\mathrm{BM}$. A randomized crossover study of silver-coated urinary catheters in hospitalized patients. Arch Intern Med 2000;160:3294-8.

9. Gentry H, Cope S. Using silver to reduce catheterassociated urinary tract infections. Nurs Stand 2005;19:514.

10. Newton T, Still JM, Law E. A comparison of the effect of early insertion of standard latex and silver-impregnated latex foley catheters on urinary tract infections in burn patients. Infect Control Hosp Epidemiol 2002;23:217-8.

11. Gould CV, Umscheid CA, Agarwal RK, Kuntz G, Pegues DA; Healthcare Infection Control Practices Advisory Committee. Guideline for prevention of catheterassociated urinary tract infections 2009. Infect Control Hosp Epidemiol 2010;31:319-26.

12. Schumm K, Lam TB. Types of urethral catheters for management of short-term voiding problems in hospitalized adults: a short version Cochrane review. Neurourol Urodyn 2008;27:738-46.

13. Seymour C. Audit of catheter-associated UTI using silver alloy-coated Foley catheters. Br J Nurs 2006;15:598-603.

14. Rupp ME, Fitzgerald T, Marion N, et al. Effect of silvercoated urinary catheters: efficacy, cost-effectiveness, and antimicrobial resistance. Am J Infect Control 2004;32:44550.

15. Verleyen P, De Ridder D, Van Poppel H, Baert L. Clinical application of the Bardex IC Foley catheter. Eur Urol 1999;36:240-6.

16. Johnson JR, Kuskowski MA, Wilt TJ. Systematic review: antimicrobial urinary catheters to prevent catheterassociated urinary tract infection in hospitalized patients. Ann Intern Med 2006;144:116-26.

17. Pickard R, Lam T, MacLennan G, et al. Antimicrobial catheters for reduction of symptomatic urinary tract infection in adults requiring short-term catheterisation in hospital: a multicentre randomised controlled trial. Lancet 2012;380:1927-35. 